\title{
THE DEVELOPMENT OF EDUCATIONAL PUZZLE GAME BASED ON THE LOCAL WISDOM USING FLASH MEDIA TO EDUCATE THE STUDENTS' CHARACTERISTIC OF PRIMARY SCHOOL
}

\author{
Herwin Widyatmoko \\ Universitas Muria Kudus \\ Email: herwinwidyatmoko07@gmail.com
}

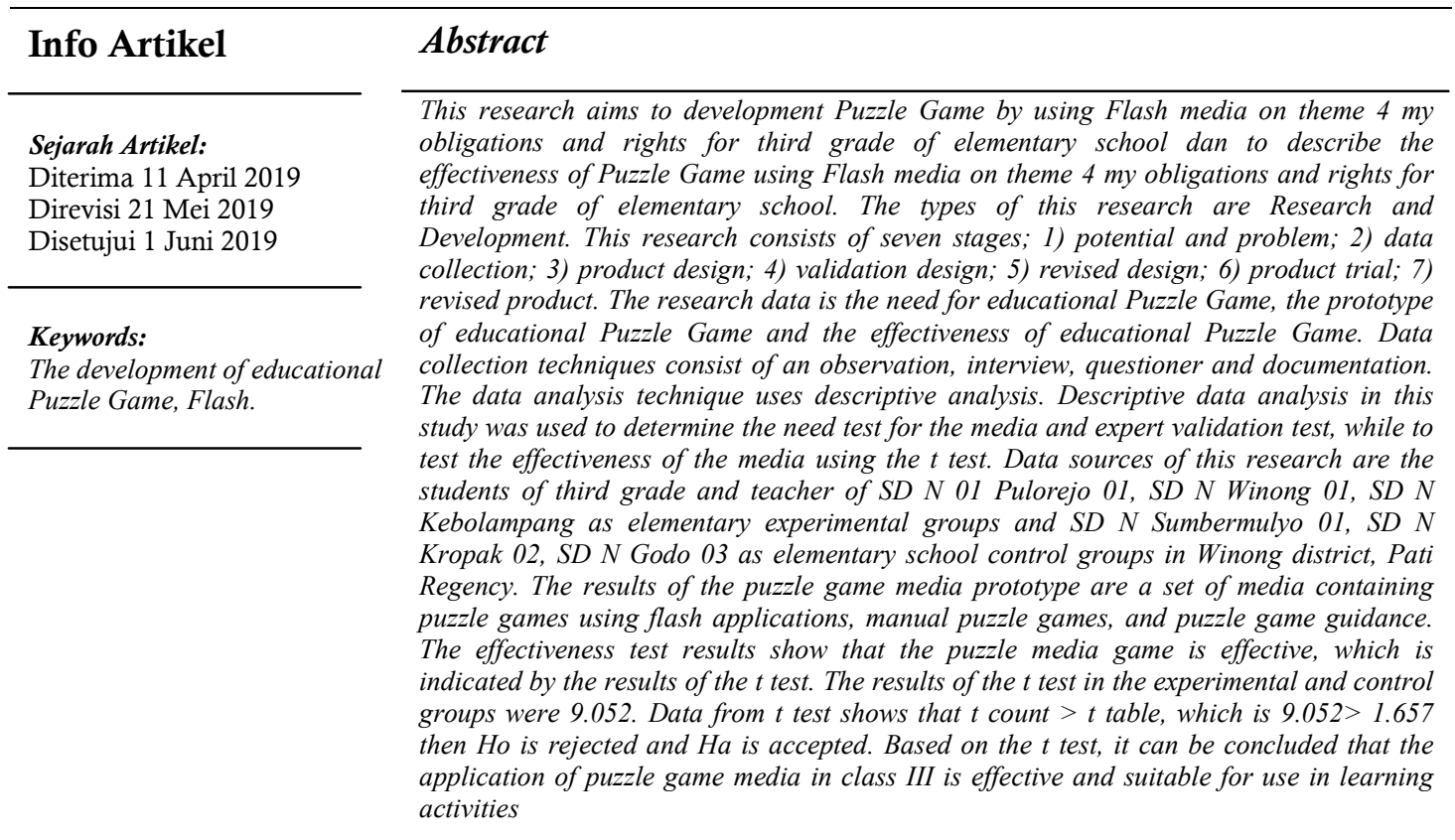

\begin{abstract}
Abstrak
Penelitian ini bertujuan untuk mengembangkan Game Puzzle bermedia Flash pada tema 4 Kewajiban dan Hakku untuk siswa SD kelas III, dan mendeskripsikan hasil uji efektivitas Game Puzzle bermedia Flash pada tema 4 Kewajiban dan Hakku untuk siswa SD kelas III. Jenis penelitian ini adalah Research and Development. Penelitian ini terdiri dari tujuh langkah, antara lain: 1) potensi dan masalah; 2) pengumpulan data; 3) desain produk; 4) validasi desain; 5) revisi desain; 6) uji coba produk, 7) revisi produk. Data pada penelitian ini adalah data tentang kebutuhan media game puzzle edukasi, prototipe dari media game puzzle edukasi dan efektivitas dari media game puzzle edukasi. Teknik pengumpulan data terdiri dari observasi, wawancara, kuesioner dan dokumentasi. Teknik analisis data menggunakan analisis deskriptif. Analisis data deskriptif pada penelitian ini digunakan untuk mengetahui uji kebutuhan terhadap media dan uji validasi ahli, sedangkan untuk menguji keefektifan media menggunakan uji t. Sumber data penelitian ini adalah siswa dan guru kelas III SD N Pulorejo 01, SD N Winong 01, SD N Kebolampang sebagai SD kelompok eksperimen dan SD N Sumbermulyo 01, SD N Kropak 02, SD N Godo 03 sebagai SD kelompok kontrol di Kecamatan Winong Kabupaten Pati. Hasil prototipe media game puzzle adalah seperangkat media yang berisi game puzzle menggunakan aplikasi flash, game puzzle manual, dan buku petunjuk game puzzle. Hasil uji keefektifan menunjukkan bahwa media game puzzle efektif, ditunjukkan dengan hasil uji t. Hasil dari uji t pada kelompok eksperimen dan kontrol yaitu 9,052. Data dari uji t menunjukkan bahwa $\mathrm{t}_{\text {hitung }}>\mathrm{t}_{\text {tabel, }}$, yaitu 9,052 $>1,657$ maka Ho ditolak dan Ha diterima. Berdasarkan uji $\mathrm{t}$ tersebut dapat disimpulkan bahwa penerapan media game puzzle di kelas III efektif dan layak digunakan dalam kegiatan pembelajaran.
\end{abstract}

(C) 2019 Universitas Muria Kudus 
Widyatmoko, Herwin

THE DEVELOPMENT OF EDUCATIONAL PUZZLE GAME BASED ON THE LOCAL WISDOM ... REFLEKSI EDUKATIKA : Jurnal Ilmiah Kependidikan, Volume 9, Nomor 2, Juni 2019, hlm 192-198

\section{INTRODUCTION}

Education is the process of forming humans in achieving life goals. Educated humans will be able to live their lives well. Education is also a step in the formation and planting of individual characters in order to be a good person and can benefit their environment. This good personality will be created by the formation of strong character from each individual since he was in elementary school through habituation. With this, students become characterized and will improve their learning outcomes. This good personality will be created by the formation of strong character from each individual since he was in elementary school through habituation. That way, students become characterized and will improve their learning outcomes. One of the learning materials that needs to be cultivated is the theme 4: My Obligations and Rights in class III. This material is very close to all daily community activities, as well as the student environment.

In instilling education and character values in learning will be maximized by the use of learning media used in teaching and learning activities. Learning media is a component that increases the intensity of interaction between teachers and students and the interaction between students and students. So, learning media can be a teaching aid that is supporting the teacher's learning method. One of the media that can be developed is the puzzle game media According to Jamil (2012: 20) Puzzles are a form of puzzle with the model of arranging pieces of the picture into a unified whole picture. Indonesian people recognize puzzles as a game of unloading. Puzzles are used as a tool that require us as players to arrange pieces / pieces of images from Puzzle.

Based on observations and interviews that the researchers did to several teachers, it was known that the learning process in class III was still conventional and dominated by lectures. This makes the learning process boring. In addition, in teaching teachers do not use teaching media that are able to invite active students. As a result students feel bored and teaching and learning activities become less effective. Learning becomes monotonous and causes student learning outcomes to be low. When viewed from the nature and character of elementary school students who are still happy to play, teaching media are needed that can encourage students to play. However, it must also be adapted to the content of the material from teaching materials developed based on advances in science and technology.

In connection with these problems, it is necessary to develop an interesting teaching media so that it can encourage students to improve their learning outcomes. Development is done by making innovative and fun learning media. Through innovative learning media learning will be meaningful and students can play while learning so it is not saturated. Therefore, this learning can be achieved with the development of flash media puzzle games.

The purpose of this study is 1) develop Flash Puzzle media teaching media on the theme 4 Obligations and My Rights for grade III elementary school students; 2) describe the results of testing the effectiveness of Game Puzzle media in Flash on the theme 4 Obligations and My Rights for elementary school students in class III.

Husna (2017: 67) explains that puzzles are a kind of game in the form of pieces of pictures that are how to play, namely by arranging them to form an image, with the aim of exercising patience, making it easier for students to understand concepts, solve problems, cooperate with friends, and develop students' motor and cognitive skills. According to Wahyuni (in Husna, 2017: 67) the puzzle has several advantages, namely: (1) puzzle games can attract students' interest in learning, (2) images on the puzzle can overcome the limitations of space and time, because not all objects can be brought to in class, (3) with the presence of learning media students can see, observe, experiment and can add insight.

Macromedia flash has several types (versions), one of which is Macromedia flash 8. Macromedia flash 8 is a multimedia program that is used to create very interesting vector animations. Usually this program is used for the purpose of creating interactive and dynamic web sites, including the creation of logo animations, games, making short films or cartoons, presentations, advertisements, making animated buttons, interactive menus, screen savers and the overall creation of other web contents. Animations made with flash will still look good 
Widyatmoko, Herwin

THE DEVELOPMENT OF EDUCATIONAL PUZZLE GAME BASED ON THE LOCAL WISDOM ...

REFLEKSI EDUKATIKA : Jurnal Ilmiah Kependidikan, Volume 9, Nomor 2, Juni 2019, hlm 192-198

even with the resolution and size of any Windows screen (Sulastri, 2015: 7).

Rahyono (2009: 7) defines local wisdom as an intelligence possessed by certain ethnic groups, which is obtained through ethnic experience that grapples with their environment. Local wisdom can strengthen the identity of a nation and country. In addition to local wisdom, character education is also very important in strengthening the personalities of the nation and state. According to Kesuma (2012: 4) character education is a term that is increasingly gaining recognition from today's Indonesian society.

\section{RESEARCH METHOD}

The type of research used in this study is Research and Development (R \& D). According to Sugiyono (2013: 407) Research and Development (R \& D) is a research method used to produce a particular product, and test the effectiveness of the product. Steps in the type of Research And Development (R \& D) research, including: 1) potential and problems, 2) data collection, 3) product design, 4) design validation, 5) design revisions, 6) product testing, 7) product revisions, 8) usage trials, 9) product revisions, 10) mass production. Research and development designs can be illustrated in the following chart

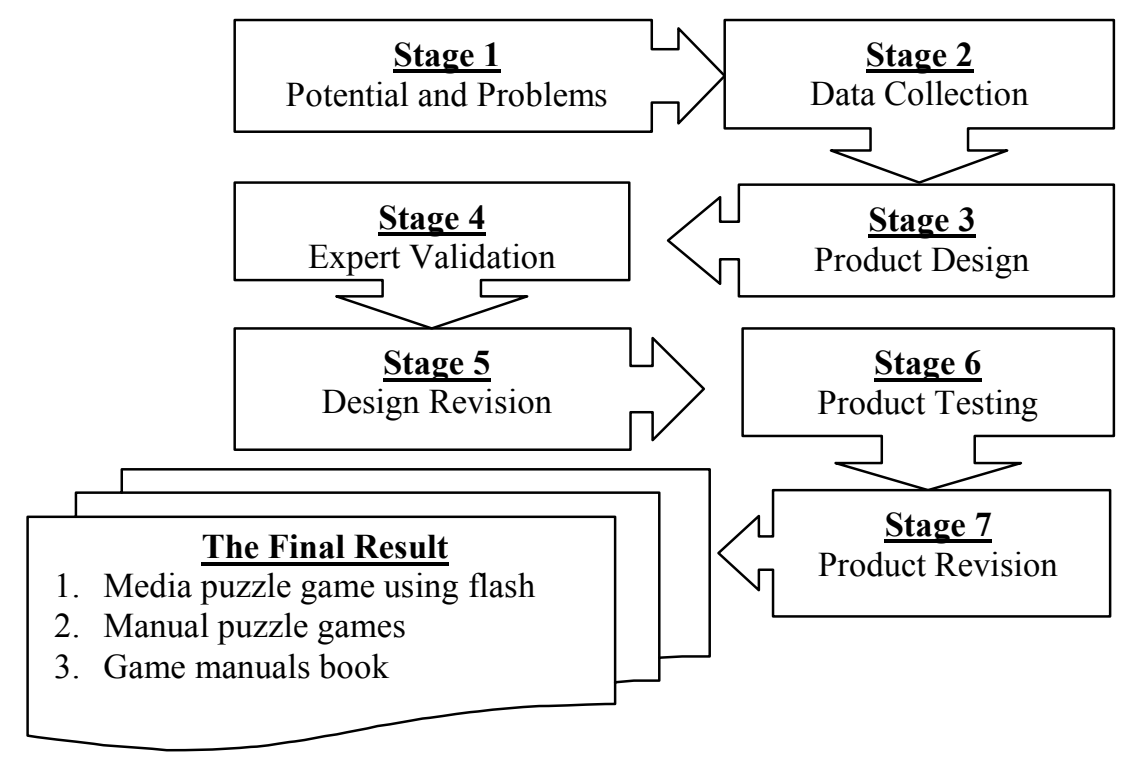

Figure 1. Chart of Research Procedures

This research and development was carried out in several schools in class III namely SD N Pulorejo 01, SD N Winong 01, SD N Kebolampang as an experimental group and SD N Sumbermulyo 01, SD N Kropak 02, SD N Godo 03 as elementary school control groups in Winong Subdistrict Pati Regency.

The data analysis technique used is descriptive analysis techniques. Qualitative data was obtained from two data, including: (1) data analysis of the needs of students and teachers for the development of puzzle media games using flash, and (2) expert test analysis data as a process of revision of media prototypes. The data analysis step is described as follows.

1. Calculate the average total score for each component using the following formula.

$$
\underline{X i=\frac{\sum x}{n}}
$$

Information:

$\mathrm{Xi}=$ average score

$\sum x=$ number of scores

$n=$ number of assessors

2. Calculate the average total score of each component 
3. Change the average score into a qualitative form, referring to the categorization, as follows.

Table 1. Quantitative Data Conversion to $n_{1}$ Scale 4 Qualitative

\begin{tabular}{cc}
\hline Conversion Value & Classification \\
\hline $81 \%-100 \%$ & Very Good \\
\hline $61 \%-80 \%$ & Good \\
\hline $41 \%-60 \%$ & Enough \\
\hline $0 \%-40 \%$ & Less \\
\hline
\end{tabular}

Products developed can be said to be feasible, if the results of the assessment of field trials are minimal in good criteria.

To see the effectiveness of learning media used a technique called the t-test according to Arikunto (2010: 349). The steps for analyzing the data are as follows:

1. Look for the average value of the first group test and the average value of the second group test

2. Test the average difference with the t-test whose formula is as follows.

$t=\frac{x_{1}-x^{2}}{s \sqrt{1 / n 1+1 / n 2}}$
Information:

$x_{1} \quad=$ The first sample average

$x_{2} \quad=$ The second sample average

$=$ The first number of sample members

$=$ The second number of sample members

$s \quad=$ Shared variant

\section{FINDING AND DISCUSSION}

The media effectiveness test data is obtained from the questions given to students in several elementary schools. Questions were given to the experimental group and the control group.

Table 2. Data on Experimental Group and Control Group Values

\begin{tabular}{cccc}
\hline $\begin{array}{c}\mathbf{N} \\
\text { o. }\end{array}$ & Value & $\begin{array}{c}\text { Experimental } \\
\text { Group }\end{array}$ & $\begin{array}{c}\text { Control } \\
\text { Group }\end{array}$ \\
\hline 1. & The highest score & 96 & 84 \\
\hline 2. & The lowest score & 60 & 40 \\
\hline 3. & Average value & 79,66 & 61,45 \\
\hline \multicolumn{4}{r}{ Source: Researcher (Primary Data) }
\end{tabular}

Based on the table above, the value of the experimental and control groups can be presented in the diagram as follows.

\section{Figure 2. Average Diagram of Experiment and Control Values}

To describe the effectiveness of the puzzle media, a prerequisite test was conducted and the field trials were limited, as follows.

1. Prerequisites Test

a. Normality Test

The normality test is done to describe whether between the experimental group and the control group is normally distributed or not. The results of the normality test using SPSS as follows. 
Widyatmoko, Herwin

THE DEVELOPMENT OF EDUCATIONAL PUZZLE GAME BASED ON THE LOCAL WISDOM ...

REFLEKSI EDUKATIKA : Jurnal Ilmiah Kependidikan, Volume 9, Nomor 2, Juni 2019, hlm 192-198

Table 3. NormalityTest of Experimental and

\begin{tabular}{cccccccc}
\hline Control Groups & \multicolumn{3}{l}{$\begin{array}{l}\text { Kolmogorov- } \\
\text { Class }\end{array}$} & \multicolumn{4}{c}{ Shirnov } \\
\cline { 3 - 8 } & & Statistik & Df & Sig. & Statistik & Df & Sig. \\
\hline $\begin{array}{l}\text { Learning } \\
\text { outcomes }\end{array}$ & Experiment &, 111 & 58 &, 072 &, 949 & 58 &, 016 \\
& Control &, 096 & 69 &, 187 &, 969 & 69 &, 086 \\
\hline
\end{tabular}

a. Lilliefors Significance Correction

Source: Researcher (Normality Test in Class III)

Based on Kolmogorov-Smirnov, a significance value of $>\alpha=5 \%$ is obtained. The experimental group is $0.072>0.05$ and the control group is $0.187>0.05$. This shows that the value data in the experimental group and value data in the control group are normally distributed. b. Homogeneity Test

Homogeneity tests were conducted to show whether the experimental group and the control group had the same variance or not. The homogeneity test results are as follows.

Table 4. Homogeneity Test of Experimental and Control Groups

\begin{tabular}{cccc}
\hline $\begin{array}{c}\text { Levene } \\
\text { Statisti } \\
\text { c }\end{array}$ & $\begin{array}{c}\text { Df } \\
\mathbf{1}\end{array}$ & Df2 & Sig. \\
\hline, 653 & 1 & 125 &, 420 \\
\hline
\end{tabular}

Source: Researcher (Homogeneity Test in Class III)

Based on the homogeneity test, obtained significance, then $\mathrm{H} 0$ is accepted and the data is homogeneous (same). Due to the significance of $0.420>0.05$, it can be concluded that the data is homogeneous.

\section{Limited Field Trials}

To test the effectiveness of the use of flash media media puzzle games, a field trial was conducted. To describe the effectiveness of the media used t-test based on the value of the SD experimental group and the SD control group. Value data were analyzed with a significance level of 0.05 . This analysis technique is used to indicate the presence or absence of the effect of the treatment of media use of puzzle games media flash on the object of research.

The results showed that the development of puzzle games had a positive effect on learning in class 3. Students in the experimental group scored better than students in the control group. Students in the experimental group were enthusiastic in learning because the teacher used media puzzle games, while in the control group the teacher did not use media puzzle games. The learning process with this puzzle game becomes fun, students become active in learning activities. In addition, students can play while learning so that they are not bored in the classroom and there is a reciprocity between the teacher and the students well.

With the application of this puzzle game, the learning process becomes meaningful, the teacher becomes creative in managing learning. The teacher becomes easy in delivering the material and students easily understand the learning material.

Based on the $\mathrm{t}$ test obtained $\mathrm{t}$ count $>\mathrm{t}$ table, which is 9,052 $>1,657$ then Ho is rejected and $\mathrm{Ha}$ is accepted. So, it can be concluded that the use of flash media media puzzle games is effectively applied in grade III elementary school.

The findings are supported by research results from Iskandar (2014) in his research entitled "Media Development Puzzle Games in Middle School Students with Human Digestive System Material". This study aims to describe the feasibility of the media and the response of 
Widyatmoko, Herwin

THE DEVELOPMENT OF EDUCATIONAL PUZZLE GAME BASED ON THE LOCAL WISDOM ... REFLEKSI EDUKATIKA : Jurnal Ilmiah Kependidikan, Volume 9, Nomor 2, Juni 2019, hlm 192-198

students to the puzzle media in the material of Human Digestive System. The results showed that the media feasibility of $86.45 \%$ was included in the very feasible category. Students give a very strong response to the Puzzle game.

\section{CONCLUSION}

Based on the results of research and discussion can be concluded as follows.

1. The media puzzle game media flash, contains the material theme 4 of my obligations and rights in class III. The media puzzle game includes media flash puzzle games, manual puzzle games, and persuasion books for puzzle games. This set of media puzzle games can make learning interesting for students and teachers. The game comes with colorful and varied background images. The game is also equipped and accompanied by national songs as a generator of nationalism to foster the character of students as Indonesian citizens. Through the development of this puzzle game learning is packaged into interactive learning in the classroom.

2. The results of the effectiveness test show that flash media media puzzle games are effectively used in learning. The results of the $t$ test in the experimental and control groups were 9.052. Data from $t$ test shows that $t$ count $>\mathrm{t}$ table, which is $9.052>1.657$ then $\mathrm{Ho}$ is rejected and $\mathrm{Ha}$ is accepted. Based on the $t$ test, it can be concluded that the application of puzzle game media in class III has a significant difference, so the media media flash puzzle game is effective and suitable for use in learning activities.

\section{SUGGESTION}

Based on these conclusions, the suggestions that can be submitted are as follows.

1. The teacher is expected to be able to develop innovative learning media in learning activities.

2. Media flash puzzle media games can be an alternative for teachers in delivering learning material, especially on the theme of my obligations and rights in class III.

3. This learning media can be further developed by teachers with different material.

\section{REFERENCES}

Arikunto, Suharsimi. 2010. Prosedur Penelitian Suatu Pendekatan Praktik. Jakarta: PT. Rineka Cipta.

Arsyad, Azhar. 2017. Media Pembelajaran. Jakarta: PT. Raja Grafindo Persada.

Fadhli, Aulia. 2010. Koleksi Games Seru \& Kreatif untuk Meningkatkan IQ dan ESQ Anak. Yogyakarta: Pustaka Marwa.

Fitri, Agus Zaenul. 2012. Pendidikan Karakter Berbasis Nilai \& Etika Di Sekolah. Yogyakarta: Ar-Ruzz Media.

Hainey, T., Conolly, TM., \& Razak, AA. 2012. Teacher's Views on The Approach of Digital Games-Based Learning Within the Curriculum for Exellence. Intl. J. Games Based Learning. 2(1): 33-51.

Herawati, Nanik. 2012. Kearifan Lokal Bagian Budaya Jawa. Jurnal Magistra, 79. (XXIV): 64.

Husna, Nurul. 2017. Pengembangan Media Puzzle Materi Pencemaran Lingkungan di SMP Negeri 4 Banda Aceh. Jurnal Pendidikan Sains Indonesia, 05 (01): 6671.

Iskandar, Mariska Regina. 2014. Pengembangan Media Permainan Puzzle pada Siswa SMP dengan Materi Sistem Pencernaan Manusia. Jurnal Pendidikan Sains, 2 (03).

Jamil, Sya'ban. 2012. 56 Games untuk Keluarga. Jakarta: Republika Penerbit.

Kesuma, Dharma dkk. 2012. Pendidikan Karakter Kajian Teori dan Praktik di Sekolah. Bandung: PT. Remaja Rosdakarya.

Murbarani, Andhini. 2014. Pengembangan Media Puzzle Elektronik tentang Rangka Tubuh Manusia pada Mata Pelajaran IPA untuk Meningkatkan Hasil Belajar Siswa Kelas IV di SDN Jombatan V Jombang. Jurnal Mahasiswa Teknologi Pendidikan, $5(3)$. 
Widyatmoko, Herwin

THE DEVELOPMENT OF EDUCATIONAL PUZZLE GAME BASED ON THE LOCAL WISDOM ...

REFLEKSI EDUKATIKA : Jurnal Ilmiah Kependidikan, Volume 9, Nomor 2, Juni 2019, hlm 192-198

Pelletiere, C. 2009. Games and Learning. International Journal of Learning and Media. 1(1): 84-100.

Purwanto. 2014. Evaluasi Hasi Belajar. Surakarta: Pustaka Pelajar.

Rahmawati, Erlin Septiana. 2014. Pengembangan Media Pembelajaran Puzzle Berbasis Adobe Flash CS5 sebagai Media Interaktif Materi Menyusun Rekonsiliasi Bank. Jurnal Pendidikan Akuntansi, 2(2).

Rahyono, F.X. 2009. Kearifan Budaya Dalam Kata. Jakarta: Wedatama Widyasastra.

Rohani, Ahmad. 2014. Media Instructional Edukatif. Jakarta: Rineka Cipta.

Rumakhit, Nur. 2016. Pengembangan Media Puzzle untuk Pembelajaran Materi Mengidentifikasi Beberapa Jenis Simbiosis Dan Rantai Makanan Kelas IV
Sekolah Dasar Tahun 2016/2017. SimkiPedagogia, 01 (02).

Sugiyono. 2013. Metode Penelitian Pendidikan Pendekatan Kuantitatif, Kualitatif, dan R \& D. Bandung: Alfabeta.

Sulastri, Ika Wiji. 2015. Pengembangan Media Pembelajaran Interaktif Dengan Macromedia Flash 8 Pada Mata Pelajaran Korespondensi.

(http://jurnalmahasiswa.unesa.ac.id/index php/ipap/article/view/15062, diakses pada tanggal 05 Juni 2018). Universitas Negeri Surabaya.

Tybon, R \& K. Don. 2009. Automated Solutions to Incomplete Jigsaw Puzzle. Artificial Intelligence Review. 32(1-4):77-79

Vitianingsih, Anik Vega. 2016. Game Edukasi Sebagai Media Pembelajaran Pendidikan Anak Usia Dini. Jurnal Inform, 1 (1).. 